\title{
Herbaspirillum canariense sp. nov., Herbaspirillum aurantiacum sp. nov. and Herbaspirillum soli sp. nov., isolated from volcanic mountain soil, and emended description of the genus Herbaspirillum
}

Correspondence Encarna Velázquez evp@usal.es

\author{
Lorena Carro, ${ }^{1}$ Raúl Rivas, ${ }^{1}$ Milagros León-Barrios, ${ }^{2}$ \\ María González-Tirante, ${ }^{3}$ Encarna Velázquez ${ }^{1}$ and Angel Valverde ${ }^{3}$ \\ 'Departamento de Microbiología y Genética, Universidad de Salamanca, Salamanca, Spain \\ ${ }^{2}$ Departamento de Microbiología y Biología Celular, Universidad de la Laguna, Tenerife, Spain \\ ${ }^{3}$ Instituto de Recursos Naturales y Agrobiología, CSIC, Salamanca, Spain
}

The genus Herbaspirillum belongs to the family Oxalobacteraceae within the class Betaproteobacteria, with Herbaspirillum seropedicae as the type species (Baldani et al., 1986). Since the description of $H$. seropedicae, ten additional species have been described, one of which, Herbaspirillum putei, was recently reclassified as a subspecies of Herbaspirillum huttiense (Dobritsa et al., 2010). The members of the genus Herbaspirillum have been found in waters (Ding \& Yokota, 2004) and in association with plant tissues (Baldani et al., 1986; Kirchhof et al., 2001; Valverde et al., 2003; Rothballer et al., 2006), the plant rhizosphere (Jung et al., 2007) and soil (Im et al., 2004).

During screening to search for bacteria with plant growth promotion (PGPR) potential, we isolated three

The GenBank/EMBL/DDBJ accession numbers for the 16S rRNA gene sequences of strains SUEMIO3 ${ }^{\top}$, SUEMIO8 $^{\top}$ and SUEMI $10^{\top}$ are HQ830496, HQ830497 and HO830498, respectively.

Three supplementary figures and two supplementary tables are available with the online version of this paper. siderophore-producing strains from an old volcanic mountain soil in the north-east of Tenerife (Canary Islands). The vegetation at this site is dominated by herbaceous nitrophilous communities with species such as Galactites tomentosa, Calendula arvensis, Oxalis pes-caprae, Sinapis arvensis and Brachypodium distachyon. Patches of diverse shrubs and plantations of Eucalyptus globulus are also common. The bacterial isolates were classified in the genus Herbaspirillum after $16 \mathrm{~S}$ rRNA gene sequence analysis. The phenotypic and genetic characteristics of these strains showed that SUEMI03 $3^{\mathrm{T}}$, SUEMI0 ${ }^{\mathrm{T}}$ and SUEMI $10^{\mathrm{T}}$ belong to three novel species of the genus Herbaspirillum.

The strains were isolated on TSA medium (Difco) containing $1 \%$ soil extract prepared by suspending $10 \mathrm{~g}$ of the same soil from which the strains were isolated in $90 \mathrm{ml}$ sterile water that was maintained under shaking conditions for $2 \mathrm{~h}$. Then, $10 \mathrm{ml}$ of this suspension was added to $90 \mathrm{ml}$ water to which the corresponding amount of TSA powder was added. The medium was sterilized by 
autoclaving at $121{ }^{\circ} \mathrm{C}$ for $20 \mathrm{~min}$ and dispensed into Petri dishes. Decimal dilutions of the soil extract were obtained and $1 \mathrm{ml}$ from each dilution was spread on these plates. The strains isolated were transferred to Petri dishes containing M9-CAS agar (Alexander \& Zuberer, 1991) and three colonies surrounded by an orange halo indicative of siderophore production were transferred to TSA plates for identification.

The strains were grown in nutrient broth (Difco) for $48 \mathrm{~h}$ at $22{ }^{\circ} \mathrm{C}$ to check for motility by phase-contrast microscopy using the hanging drop method. Gram staining was carried out by the procedure described by Doetsch (1981) after $24 \mathrm{~h}$ of incubation at $28{ }^{\circ} \mathrm{C}$. The flagellation type was determined by electron microscopy after $48 \mathrm{~h}$ of incubation of strains in TSB at $22{ }^{\circ} \mathrm{C}$ as described previously (Rivas et al., 2007). The three strains were Gram-negative short rods, motile by a polar flagellum (Fig. S1, available in IJSEM Online).

The 16S rRNA genes of strains SUEMI03 ${ }^{\mathrm{T}}$, SUEMI08 ${ }^{\mathrm{T}}$ and SUEMI $10^{\mathrm{T}}$ were analysed as described by Rivas et al. (2007). The sequences obtained were compared with those from GenBank using the BLASTN (Altschul et al., 1990) and EzTaxon (Chun et al., 2007) programs. Sequences were aligned using the CLUSTAL_X software (Thompson et al., 1997). Distances were calculated according to Kimura's two-parameter model (Kimura, 1980). The phylogenetic tree was inferred using the neighbour-joining (Saitou \& Nei, 1987), maximum-parsimony (Felsenstein, 1983) and maximum-likelihood (Rogers \& Swofford, 1998) methods. Bootstrap analysis was based on 1000 resamplings. MEGA4 (Tamura et al., 2007) was used for neighbour-joining and maximum-parsimony analyses and ARB (Ludwig et al., 2004) was used for maximum-likelihood analysis. The resulting neighbour-joining tree is shown in Fig. 1 and those obtained using maximum-parsimony and maximum-likelihood in Figs S2 and S3, respectively.

The results of the phylogenetic analyses showed that the strains isolated in this study belong to the genus Herbaspirillum, forming a cluster clearly divergent from the remaining species of this genus (Figs 1, S2 and S3). All phylogenetic analysis showed that the genus Herbaspirillum does not constitute a compact group, since the species Herbaspirillum hiltneri, $H$. lusitanum, $H$. rhizosphaerae and $H$. autotrophicum formed a separated cluster. However, the three strains isolated in this study clearly belong to the genus Herbaspirillum, because all analysis showed that the closest related species in all cases was H. seropedicae, the type species of the genus (Figs 1, S2 and S3). The type strain of this species, DSM $6445^{\mathrm{T}}$, presented $97.5,97.8$ and $97.7 \% 16 \mathrm{~S}$ rRNA gene sequence similarity, respectively, with respect to strains SUEMI03 ${ }^{\mathrm{T}}$, SUEMI08 ${ }^{\mathrm{T}}$ and SUEMI $10^{\mathrm{T}}$ according to the EzTaxon program. The $16 \mathrm{~S}$ rRNA gene sequence similarity between the three isolates from this study was $99.2 \%$ between SUEMI $3^{\mathrm{T}}$ and SUEMI08 ${ }^{\mathrm{T}}, 99.6 \%$ between SUEMI03 ${ }^{\mathrm{T}}$ and SUEMI $10^{\mathrm{T}}$ and $99.5 \%$ between SUEMI $08^{\mathrm{T}}$ and SUEMI $10^{\mathrm{T}}$. Similarities higher than those found between SUEMI $10^{\mathrm{T}}$ and the two other strains have been reported between other Herbaspirillum species: for example, $99.9 \%$ identity between the type strains of H. hiltneri and H. lusitanum (Rothballer et al., 2006) or $99.8 \%$ identity between those of $H$. aquaticum and $H$. huttiense (Dobritsa et al., 2010).

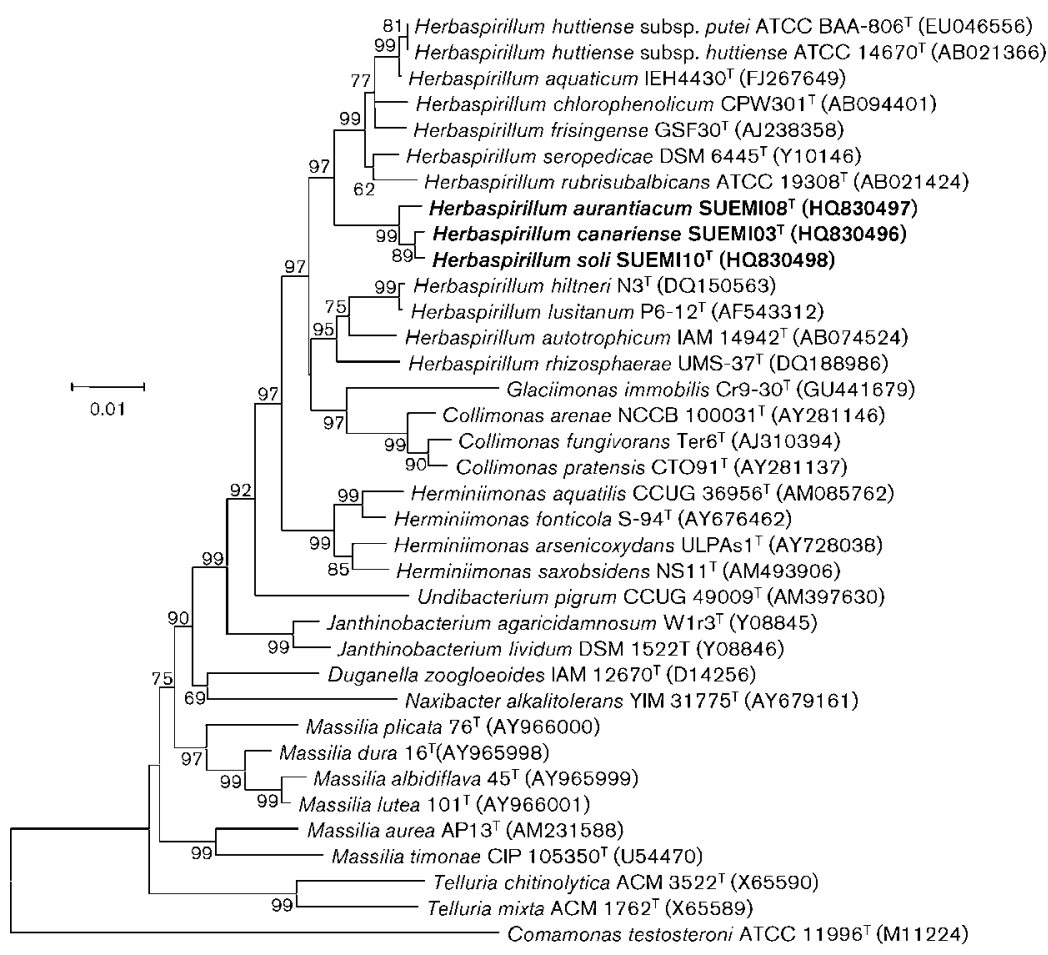

81 Herbaspirillum huttiense subsp. putei ATCC BAA-806 ${ }^{\mathrm{T}}$ (EU046556)

(14670' (AB021366)

(ABO21424)

- Herbaspirillum aurantiacum SUEMI08 ${ }^{\top}$ (H0830497)

90 Collimonas pratensis CTO9 $1^{\top}$ (AY281137)

Herminimonas aquailis

in̈̈monas arsenicoxydans ULPAs1T (AY72803B)

Herminimonas saxobsidens NS11 ${ }^{\mathrm{T}}$ (AM493906)

bacterium agaricidamnosum $\mathrm{W}_{1 \mathrm{r} \mathrm{B}^{\top}}$ (Y08845)

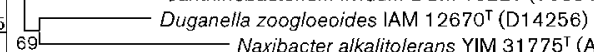

Massilia picala $76^{\top}$ (AY966000)

- Massilia dura 16'(AY965998)

- Massilia albidifiava 45T (AY965999)

- Telluria mixta ACM $1762^{\top}$ (X65589)

Comamonas testosteroni ATCC $11996^{\top}$ (M11224)
Fig. 1. Neighbour-joining tree based on nearly complete 16S rRNA gene sequences of Herbaspirillum canariense sp. nov. SUEMI03 ${ }^{\top}$, Herbaspirillum aurantiacum sp. nov. SUEMI08 ${ }^{\top}$ and Herbaspirillum soli sp. nov. SUEMI $10^{\top}$ and currently accepted species and subspecies within the genus Herbaspirillum. The significance of each branch is indicated by a bootstrap value calculated for 1000 subsets. Bar, 1 substitution per 100 nucleotide positions. 
DNA-DNA hybridization experiments were carried out by using the method of Ezaki et al. (1989) following the recommendations of Willems et al. (2001). DNA samples from strains SUEMI03 ${ }^{\mathrm{T}}$, SUEMI08 ${ }^{\mathrm{T}}$ and SUEMI $10^{\mathrm{T}}$ were hybridized with each other and with DNA from $H$. seropedicae DSM $6445^{\mathrm{T}}$. Strains SUEMI03 ${ }^{\mathrm{T}}$, SUEMI08 ${ }^{\mathrm{T}}$ and SUEMI $10^{\mathrm{T}}$ showed 25,12 and $11 \%$ DNA relatedness, respectively, with respect to $H$. seropedicae DSM $6445^{\mathrm{T}}$. Strain SUEMI03 ${ }^{\mathrm{T}}$ showed 58 and $59 \%$ relatedness with respect to SUEMI08 ${ }^{\mathrm{T}}$ and SUEMI $10^{\mathrm{T}}$, respectively, and strains SUEMI $08^{\mathrm{T}}$ and SUEMI $10^{\mathrm{T}}$ showed $59 \%$ interstrain relatedness. In the case of the species mentioned above, $25 \%$ DNA-DNA relatedness was found between the type strains of $H$. hiltneri and $H$. lusitanum (Rothballer et al., 2006) and 40-59\% between the type strains of $H$. aquaticum and $H$. huttiense (Dobritsa et al., 2010). All these values are lower than the currently accepted threshold value of $70 \%$ DNA-DNA relatedness for definition of bacterial species (Wayne et al., 1987), and we therefore consider that the strains isolated in this study represent three novel species of the genus Herbaspirillum.

DNA for analysis of DNA base composition was prepared according to Chun \& Goodfellow (1995) and the G+C content was determined using the thermal denaturation method (Mandel \& Marmur, 1968). The DNA G+C contents of strains SUEMI03 ${ }^{\mathrm{T}}$, SUEMI08 ${ }^{\mathrm{T}}$ and SUEMI $10^{\mathrm{T}}$ were $61.6,60.4$ and $61.9 \mathrm{~mol} \%$, respectively.

The presence of the nifD and nifH genes was analysed by using primers FdB261 and FdB260 (for nifD) and PolF and PolR (for nifH) under conditions described previously by Stoltzfus et al. (1997) and Poly et al. (2001), respectively. These genes were not amplified from any of the strains isolated in this study. Although these genes are carried by H. seropedicae (Baldani et al., 1986), negative results have also been obtained for other Herbaspirillum species, such as H. rhizosphaerae (Jung et al., 2007), H. chlorophenolicum (Im et al., 2004), H. autotrophicum and H. huttiense (Ding \& Yokota, 2004) and H. hiltneri (Rothballer et al., 2006).

Cellular fatty acids were analysed by using the Microbial Identification System (MIDI; Microbial ID) Sherlock 6.1 and the library RTSBA6 according to the technical instructions provided with this system (Sasser, 1990). The strains were grown on TSA plates (Difco) for $48 \mathrm{~h}$ at $28{ }^{\circ} \mathrm{C}$ and the biomass was then recovered and lyophilized. $H$. seropedicae DSM $6445^{\mathrm{T}}$ was included in this analysis together with the strains isolated in this study. The major fatty acids of the strains isolated in this study were $\mathrm{C}_{16: 0}$ and those summed in features $3\left(\mathrm{C}_{16: 1} \omega 6 c\right.$ and/or $\left.\mathrm{C}_{16: 1} \omega 7 c\right)$ and $8\left(\mathrm{C}_{18: 1} \omega 6 c\right.$ and/or $\left.\mathrm{C}_{18: 1} \omega 7 c\right)$, as occurs in the remaining species of the genus Herbaspirillum (Table S1). The fatty acid profiles of the three strains isolated in this study were similar, although $\mathrm{C}_{10: 0}$ and 11-methyl $\mathrm{C}_{18: 1} \omega 7 c$, present in small amounts in $\mathrm{SUEMI08}^{\mathrm{T}}$ and SUEMI10 ${ }^{\mathrm{T}}$, were not detected in strain SUEMI03 ${ }^{\mathrm{T}}$. The latter strain also contained larger amounts of $\mathrm{C}_{18: 0}$ than the other two strains. The fatty acids iso- $\mathrm{C}_{16: 0}$ and $\mathrm{C}_{17: 0}$ cyclo, present in small amounts in $\mathrm{SUEMI08}^{\mathrm{T}}$, were not detected in SUEMI $03^{\mathrm{T}}$ and SUEMI $10^{\mathrm{T}}$. Finally, strain SUEMI $10^{\mathrm{T}}$ differed from the other two strains in the amounts of $\mathrm{C}_{18: 0}, \mathrm{C}_{10: 0} 3-\mathrm{OH}$ and summed feature 8 . The three strains differed from $H$. seropedicae DSM $6445^{\mathrm{T}}$ in the absence of $\mathrm{C}_{12: 0} 2-\mathrm{OH}$ and $\mathrm{C}_{12: 0} 3-\mathrm{OH}$ and in the amounts of $\mathrm{C}_{12: 0}, \mathrm{C}_{14: 0}, \mathrm{C}_{10: 0} 3-\mathrm{OH}$ and summed feature 3 (Table 1). Strain SUEMI03 ${ }^{\mathrm{T}}$ also presented slight differences in the amounts of $\mathrm{C}_{18: 0}$, strain SUEMI08 ${ }^{\mathrm{T}}$ also differed in the presence (in small amounts) of iso- $\mathrm{C}_{16: 0}$ and 11-methyl $\mathrm{C}_{18: 1} \omega 7 c$ and, finally, strain SUEMI $10^{\mathrm{T}}$ also presented slight differences in the amounts of $\mathrm{C}_{18: 0}, \mathrm{C}_{16: 0}$, 11-methyl $\mathrm{C}_{18: 1} \omega 7 c$ and summed feature 8.

The strains were cultivated for 3 days on TSA at $28{ }^{\circ} \mathrm{C}$ to obtain the cell mass required for isoprenoid quinone analysis, which was carried out by the Identification Service and Dr Brian Tindall at the DSMZ (Braunschweig, Germany). The three strains contained Q-8 as the predominant ubiquinone, as has been reported for other species of the genus Herbaspirillum (Im et al., 2004; Ding \& Yokota, 2004). Strains SUEMI03 ${ }^{\mathrm{T}}$ and SUEMI08 ${ }^{\mathrm{T}}$ also contained Q-7 (4\%) and Q-9 (3\%), respectively, whereas only Q-8 was detected in strain SUEMI10 ${ }^{\mathrm{T}}$.

Table 1. Cellular fatty acid composition of the strains isolated in this study and their closest relative, $H$. seropedicae DSM $6445^{\top}$

Strains: $1, H$. canariense sp. nov. SUEMI03 ${ }^{\mathrm{T}} ; 2, H$. aurantiacum $\mathrm{sp}$. nov. SUEMI08 ${ }^{\mathrm{T}}$; 3, H. soli sp. nov. SUEMI $10^{\mathrm{T}}$; 4, H. seropedicae DSM $6445^{\mathrm{T}}$. ND, Not detected.

\begin{tabular}{|lcccc|}
\hline Fatty acid & $\mathbf{1}$ & $\mathbf{2}$ & $\mathbf{3}$ & $\mathbf{4}$ \\
\hline Saturated straight-chain & & & & \\
$\quad \mathrm{C}_{10: 0}$ & $\mathrm{ND}$ & 0.5 & 0.5 & 0.2 \\
$\mathrm{C}_{12: 0}$ & 3.3 & 3.2 & 4.3 & 0.8 \\
$\mathrm{C}_{14: 0}$ & 1.1 & 1.1 & 1.3 & 4.1 \\
$\mathrm{C}_{16: 0}$ & 21.8 & 20.9 & 19.0 & 23.3 \\
$\mathrm{C}_{17: 0}$ & $\mathrm{ND}$ & $\mathrm{ND}$ & $\mathrm{ND}$ & 0.2 \\
$\mathrm{C}_{18: 0}$ & 2.3 & 1.2 & 0.5 & 1.2 \\
Saturated iso-branched & & & & \\
iso-C $16: 0$ & $\mathrm{ND}$ & 0.4 & $\mathrm{ND}$ & $\mathrm{ND}$ \\
Hydroxy fatty acids & & & & \\
$\mathrm{C}_{10: 0}$ 3-OH & 5.7 & 5.3 & 8.0 & 1.9 \\
$\mathrm{C}_{12: 0}$ 2-OH & $\mathrm{ND}$ & $\mathrm{ND}$ & $\mathrm{ND}$ & 1.8 \\
$\mathrm{C}_{12: 0}$ 3-OH & $\mathrm{ND}$ & $\mathrm{ND}$ & $\mathrm{ND}$ & 4.6 \\
$\mathrm{C}_{14: 0}$ 2-OH & 2.4 & 2.4 & 2.7 & 1.4 \\
Cyclopropane fatty acids & & & & \\
$\mathrm{C}_{17: 0}$ cyclo & $\mathrm{ND}$ & 0.4 & $\mathrm{ND}$ & 0.4 \\
Unsaturated & & & & \\
$\quad 11-$ Methyl C $18: 1 \omega 7 c$ & $\mathrm{ND}$ & 0.4 & 1.5 & $\mathrm{ND}$ \\
Summed feature $3{ }^{*}$ & 42.5 & 44.3 & 45.5 & 38.9 \\
Summed feature $8^{*}$ & 20.9 & 19.3 & 16.8 & 21.2 \\
& & & & \\
\hline
\end{tabular}

* Summed features are groups of two or three fatty acids that cannot be separated by GLC using the MIDI System. Summed feature 3 contains $\mathrm{C}_{16: 1} \omega 6 c$ and/or $\mathrm{C}_{16: 1} \omega 7 c$; summed feature 8 contains $\mathrm{C}_{18: 1} \omega 6 c$ and/or $\mathrm{C}_{18: 1} \omega 7 c$. 
The strains isolated in this study were grown on TSA plates (Difco) for $24 \mathrm{~h}$ for catalase and oxidase production analysis. Catalase production was assayed by using $0.3 \%$ hydrogen peroxide with a single colony taken from a TSA plate. Oxidase activity was detected by using $N, N, N^{\prime}, N^{\prime}$ tetramethyl-1,4-phenylenediamine dihydrochloride. The ability to grow at different temperatures (from 4 to $37^{\circ} \mathrm{C}$ ) was determined on TSA plates. The ability to grow at $\mathrm{pH}$ 4.5-8 was determined on SA1 medium (Trujillo et al., 2005); PCA buffer $\left(0.4 \mathrm{M} \mathrm{Na}_{2} \mathrm{HPO}_{4}\right.$ and $0.2 \mathrm{M}$ citric acid) was used to adjust the $\mathrm{pH}$ from 4.5 to 6.5 and $0.2 \mathrm{M}$ TE buffer was used for $\mathrm{pH} 8$. The ability to grow in the presence of $\mathrm{NaCl}$ was analysed in TSB supplemented with $\mathrm{NaCl}$ to obtain final concentrations of $0.5-2 \%$. Nitrate reduction was tested in nitrate broth adjusted to $\mathrm{pH} 7$ (Claus \& Berkeley, 1986) containing $\left(1^{-1}\right) 5 \mathrm{~g}$ peptone, $3 \mathrm{~g}$ beef extract and $1 \mathrm{~g}$ potassium nitrate. Tween hydrolysis was analysed on Sierra basal medium (Sierra, 1957) containing $1 \mathrm{~g}$ Tween 20 or Tween $80 \mathrm{l}^{-1}$, which was autoclaved separately. Urease production was checked in urea broth (Fluka). Other physiological and biochemical tests were done using API 20NE, API ID32GN and API ZYM strips (bioMérieux) following the manufacturer's instructions. Although the isolates were inoculated on API $50 \mathrm{CH}$ strips using the API CHB medium recommended for Herbaspirillum species, they did not produce acid from any of the glucidic substrates included in API $50 \mathrm{CH}$ and, therefore, API ID32GN was used for phenotypic characterization of our isolates. This was a clear difference from H. seropedicae DSM $6445^{\mathrm{T}}$, which produced acid from many carbohydrates included in API $50 \mathrm{CH}$. The results were read after 3 and 5 days of incubation at $28{ }^{\circ} \mathrm{C}$. To test for natural antibiotic resistance, discs (Becton Dickinson) containing antibiotics at the following amounts were used: ampicillin $(2 \mu \mathrm{g})$, erythromycin $(2 \mu \mathrm{g})$, ciprofloxacin $(5 \mu \mathrm{g})$, penicillin (10 IU), polymyxin B (300 IU), cloxacillin $(1 \mu \mathrm{g})$, oxytetracycline $(30 \mu \mathrm{g})$, gentamicin $(10 \mu \mathrm{g})$, cefuroxime $(30 \mu \mathrm{g})$ and neomycin $(5 \mu \mathrm{g})$. The disc diffusion method was used on TSA medium (Becton Dickinson). The type strain of the most closely related species, $H$. seropedicae DSM $6445^{\mathrm{T}}$, was included in the phenotypic study as a reference. Phenotypic characteristics of the novel strains are reported in the species descriptions, and differences from $H$. seropedicae DSM $6445^{\mathrm{T}}$ are recorded in Table 2. In Table S2, the phenotypic characteristics of all species of the genus Herbaspirillum are recorded. Although the phenotypic profiles of the strains isolated in this study seem to be similar overall in comparison to that of $H$. seropedicae DSM $6445^{\mathrm{T}}$, SUEMI03 ${ }^{\mathrm{T}}$ presented 11 differences with respect to SUEMI $08^{\mathrm{T}}$ and nine differences with respect to SUEMI $10^{\mathrm{T}}$, and these two strains differed in the results of six tests. These differences were comparable to those found between $H$. hiltneri and $H$. lusitanum, with eight differences (Rothballer et al., 2006), and between H. aquaticum and H. huttiense, with four differences (Dobritsa et al., 2010).

Therefore, considering the current accepted criteria for species definition within the genus Herbaspirillum, the phylogenetic, chemotaxonomic and phenotypic characteristics of strains SUEMI03 $3^{\mathrm{T}}$, SUEMI08 ${ }^{\mathrm{T}}$ and SUEMI $10^{\mathrm{T}}$ showed that they represent three novel species, for which the names Herbaspirillum canariense sp. nov., Herbaspirillum aurantiacum sp. nov. and Herbaspirillum soli sp. nov., respectively, are proposed.

\section{Description of Herbaspirillum canariense sp. nov.}

Herbaspirillum canariense [ca.na.ri.en'se. N.L. neut. adj. canariense pertaining to the Canary Islands (Islas Canarias), where the type strain was isolated].

Gram-negative, aerobic, non-spore-forming, slightly curved rods, $1.9-1.6 \mu \mathrm{m}$ long and $1.0-1.3 \mu \mathrm{m}$ in diameter. Motile by a polar flagellum. Colonies on TSA are circular, convex, white-cream and opaque, usually $1-2 \mathrm{~mm}$ in diameter within 2 days at $28{ }^{\circ} \mathrm{C}$. Catalase- and oxidasepositive. Growth occurs at 20 and $30{ }^{\circ} \mathrm{C}$ and occurs slowly at 15 and $34{ }^{\circ} \mathrm{C}$, with optimum growth at $28{ }^{\circ} \mathrm{C}$. No growth occurs at $\mathrm{pH} 4.5$. Grows at $\mathrm{pH} 8$, with optimal growth at $\mathrm{pH} 6-8$. No growth occurs in presence of $2 \%$ $\mathrm{NaCl}$, but it does grow in the presence of $1.5 \% \mathrm{NaCl}$. The predominant quinone is Q-8. The major cellular fatty acids $(>10 \%$ of total fatty acids) are summed feature 3 $\left(\mathrm{C}_{16: 1} \omega 6 c\right.$ and/or $\left.\mathrm{C}_{16: 1} \omega 7 c\right)$, summed feature $8\left(\mathrm{C}_{18: 1} \omega 6 c\right.$ and/or $\left.\mathrm{C}_{18: 1} \omega 7 c\right)$ and $\mathrm{C}_{16: 0}$. Hydrolyses Tween 20 but not Tween 80 . Nitrate reduction is negative. $\beta$-Galactosidase, arginine dihydrolase, indole, urease and gelatinase are not produced. Aesculin and arbutin are hydrolysed. Urease is positive after 4 weeks of incubation in urea broth. In the API 20NE system, glucose, gluconate, adipate, malate and citrate are used as carbon sources. Assimilation of L-arabinose, mannitol, mannose, $\mathrm{N}$-acetylglucosamine, maltose, malate and caprate is negative. Assimilation of phenylacetate is weak. In the API ID32GN system, assimilation of glucose, sucrose, sorbitol, itaconate, suberate, acetate, lactate, 3-hydroxybenzoate, propionate, valerate, citrate, 3-hydroxybutyrate and 4-hydroxybenzoate is positive. Assimilation of maltose and L-alanine is weak. Assimilation of L-rhamnose, D-ribose, $\mathrm{N}$-acetylglucosamine, salicin, melibiose, L-fucose, L-arabinose, mannitol, inositol, glycogen, malonate, 5-ketogluconate, 2ketogluconate, caprate, L-serine, L-histidine and L-proline is negative. In the API ZYM system, production of alkaline and acid phosphatases, esterase (C4), esterase lipase (C8), leucine arylamidase, valine arylamidase and phosphohydrolase is positive. Production of lipase (C14), cystine arylamidase, trypsin, chymotrypsin, $\alpha$-galactosidase, $\beta$-galactosidase, $\beta$-glucuronidase, $\alpha$-glucosidase, $\beta$ glucosidase, $N$-acetyl- $\beta$-glucosaminidase, $\alpha$-mannosidase and $\alpha$-fucosidase is negative. Sensitive to cefuroxim, ciprofloxacin, erythromycin, gentamicin, neomycin, polymyxin $\mathrm{B}$ and tetracycline. Resistant to ampicillin, penicillin and cloxacillin. The DNA $\mathrm{G}+\mathrm{C}$ content of the type strain is $61.6 \mathrm{~mol} \%$.

The type strain is SUEMI03 ${ }^{\mathrm{T}}\left(=\mathrm{LMG} 26151^{\mathrm{T}}=\mathrm{CECT}\right.$ $7838^{\mathrm{T}}$ ), isolated from soil on Tenerife (Canary Islands). 
Table 2. Phenotypic differences among the three novel strains and their closest relative, $H$. seropedicae DSM $6445^{\top}$

Strains: 1 , H. canariense sp. nov. SUEMI03 ${ }^{\mathrm{T}} ; 2$, H. aurantiacum sp. nov. SUEMI08 ${ }^{\mathrm{T}} ; 3$, H. soli sp. nov. SUEMI10 ${ }^{\mathrm{T}}$; 4, H. seropedicae DSM $6445^{\mathrm{T}}$. W, Weakly positive.

\begin{tabular}{|c|c|c|c|c|}
\hline Characteristic & 1 & 2 & 3 & 4 \\
\hline Pigmentation & White & Orange & Pale orange & Cream brownish \\
\hline \multicolumn{5}{|l|}{ Growth in/at: } \\
\hline $2 \% \mathrm{NaCl}$ & - & - & $\mathrm{W}$ & + \\
\hline $\mathrm{pH} 4.5$ & - & - & - & + \\
\hline Nitrate reduction & - & - & - & + \\
\hline Urease $(72 \mathrm{~h})$ & - & - & - & + \\
\hline \multicolumn{5}{|l|}{ Hydrolysis of: } \\
\hline Aesculin* & + & - & - & - \\
\hline Arbutin $\dagger$ & + & + & - & - \\
\hline \multicolumn{5}{|l|}{ Growth on: } \\
\hline L-Arabinose ${ }^{\star}$ & - & - & - & + \\
\hline$N$-Acetylglucosamine & - & - & - & + \\
\hline D-Mannose $\ddagger$ & - & - & - & + \\
\hline D-Glucose $e^{*}$ & + & - & - & + \\
\hline Sucrose $\$$ & + & - & - & - \\
\hline Salicin $\S$ & - & + & - & - \\
\hline L-Rhamnose§ & - & - & - & + \\
\hline D-Ribose $\$$ & - & $\mathrm{W}$ & - & + \\
\hline L-Fucose\$ & - & - & - & + \\
\hline Mannitol\$ & - & - & - & + \\
\hline Sorbitol§ & + & - & - & + \\
\hline Inositol§ & - & - & - & + \\
\hline L-Proline\$ & - & + & - & + \\
\hline L-Alanine $\$$ & $\mathrm{w}$ & + & $\mathrm{w}$ & $\mathrm{w}$ \\
\hline L-Serine $\$$ & - & - & - & + \\
\hline 2-Ketogluconate§ & - & - & - & + \\
\hline 5-Ketogluconate $\$$ & - & - & - & + \\
\hline Adipate $\ddagger$ & + & + & + & - \\
\hline Caprate $\neq$ & - & - & - & + \\
\hline Phenylacetate $\ddagger$ & $\mathrm{w}$ & - & - & + \\
\hline Acetate $\$$ & + & + & $\mathrm{w}$ & $\mathrm{w}$ \\
\hline Suberate $\$$ & + & + & + & - \\
\hline 3-Hydroxybenzoate\$ & + & + & + & - \\
\hline 4-Hydroxybenzoate§ & + & + & $\mathrm{w}$ & - \\
\hline \multicolumn{5}{|c|}{ Enzyme activities (API ZYM) } \\
\hline Cystine arylamidase & - & - & - & + \\
\hline$\beta$-Galactosidase & - & - & - & + \\
\hline \multicolumn{5}{|l|}{ Resistance to: } \\
\hline Ampicillin $(2 \mu \mathrm{g})$ & + & - & + & + \\
\hline Penicillin (10 IU) & + & - & - & + \\
\hline
\end{tabular}

${ }^{\star}$ Data from both API 20NE and API ID32GN (after 3 days of incubation).

$\dagger$ Data from API $50 \mathrm{CH}$.

$\ddagger$ Data from API 20NE.

\$Data from API ID32GN (after 5 days of incubation).

Description of Herbaspirillum aurantiacum sp. nov.

Herbaspirillum aurantiacum (au.ran'ti.a'cum. N.L. neut. adj. aurantiacum orange-coloured).

Gram-negative, aerobic, non-spore-forming, slightly curved rods, $1.7-1.9 \mu \mathrm{m}$ long and $0.8-1.1 \mu \mathrm{m}$ in diameter. Motile by a polar flagellum. Colonies on TSA are circular, convex, orange and opaque, usually $1-2 \mathrm{~mm}$ in diameter within 2 days at $28{ }^{\circ} \mathrm{C}$. Catalase- and oxidase-positive. Growth occurs at 20 and $30{ }^{\circ} \mathrm{C}$ and occurs slowly at 15 and $34{ }^{\circ} \mathrm{C}$, with optimum growth at $28{ }^{\circ} \mathrm{C}$. No growth occurs at $\mathrm{pH} 4.5$, but growth is positive at $\mathrm{pH} 8$, with 
optimal growth at $\mathrm{pH} 6-8$. No growth occurs in the presence of $2 \% \mathrm{NaCl}$, but growth is positive at $1.5 \%$ $\mathrm{NaCl}$. The predominant quinone is Q-8. The major cellular fatty acids $(>10 \%$ of total fatty acids) are summed feature $3\left(\mathrm{C}_{16: 1} \omega 6 c\right.$ and/or $\left.\mathrm{C}_{16: 1} \omega 7 c\right)$, summed feature $8\left(\mathrm{C}_{18: 1} \omega 6 c\right.$ and/or $\left.\mathrm{C}_{18: 1} \omega 7 c\right)$ and $\mathrm{C}_{16: 0}$. Hydrolyses Tween 20 and hydrolyses Tween 80 weakly. Nitrate reduction is negative. $\beta$-Galactosidase, arginine dihydrolase, indole, urease and gelatinase are not produced. Arbutin is hydrolysed but aesculin is not. Urease is positive after 4 weeks of incubation in urea broth. In the API 20NE system, gluconate, adipate, malate and citrate are used as carbon sources. Assimilation of glucose, L-arabinose, mannitol, mannose, $\mathrm{N}$-acetylglucosamine, maltose, caprate and phenylacetate is negative. In the API ID32GN system, assimilation of salicin, itaconate, suberate, acetate, lactate, 3-hydroxybenzoate, propionate, valerate, citrate, 3-hydroxybutyrate, 4-hydroxybenzoate, L-proline and L-alanine is positive. Assimilation of Dribose is weak. Assimilation of glucose, L-rhamnose, Lfucose, L-arabinose, $\mathrm{N}$-acetylglucosamine, sucrose, maltose, melibiose, mannitol, inositol, sorbitol, glycogen, malonate, 5-ketogluconate, 2-ketogluconate, caprate, Lserine and L-histidine is negative. In the API ZYM system, production of alkaline and acid phosphatases, esterase (C4), esterase lipase (C8), leucine arylamidase, valine arylamidase and phosphohydrolase is positive. Production of lipase (C14), cystine arylamidase, trypsin, chymotrypsin, $\alpha$-galactosidase, $\beta$-galactosidase, $\beta$-glucuronidase, $\alpha$ glucosidase, $\beta$-glucosidase, $N$-acetyl- $\beta$-glucosaminidase, $\alpha$-mannosidase and $\alpha$-fucosidase is negative. Sensitive to ampicillin, penicillin, cefuroxim, ciprofloxacin, erythromycin, gentamicin, neomycin, polymyxin $\mathrm{B}$ and tetracycline. Resistant to cloxacillin. The DNA G $+\mathrm{C}$ content of the type strain is $60.4 \mathrm{~mol} \%$.

The type strain is SUEMI08 ${ }^{\mathrm{T}}\left(=\mathrm{LMG} 26150^{\mathrm{T}}=\mathrm{CECT}\right.$ $7839^{\mathrm{T}}$ ), isolated from soil on Tenerife (Canary Islands).

\section{Description of Herbaspirillum soli sp. nov.}

Herbaspirillum soli (so'li. L. gen. n. soli of soil).

Gram-negative, aerobic, non-spore-forming, slightly curved rods, $1.9 \mu \mathrm{m}$ long and $1.2 \mu \mathrm{m}$ in diameter. Motile by a polar flagellum. Colonies on TSA are circular, convex, pale orange and opaque, usually $1-2 \mathrm{~mm}$ in diameter within 2 days at $28{ }^{\circ} \mathrm{C}$. Catalase- and oxidase-positive. Growth occurs at 20 and $34{ }^{\circ} \mathrm{C}$ and is weak at 15 and $37^{\circ} \mathrm{C}$, with optimum growth at $28{ }^{\circ} \mathrm{C}$. No growth occurs at $\mathrm{pH} 4.5$, but growth is positive at $\mathrm{pH} 8$ with optimal growth at $\mathrm{pH} 6-8$. Growth is positive in the presence of $1.5 \% \mathrm{NaCl}$ and weak at $2 \% \mathrm{NaCl}$. The predominant quinone is Q-8. The major cellular fatty acids $(>10 \%$ of total fatty acids) are summed feature $3\left(\mathrm{C}_{16: 1} 1 \omega 6 \mathrm{c}\right.$ and/or $\left.\mathrm{C}_{16: 1} \omega 7 c\right)$, summed feature $8\left(\mathrm{C}_{18: 1} \omega 6 c\right.$ and/or $\left.\mathrm{C}_{18: 1} \omega 7 c\right)$ and $\mathrm{C}_{16: 0}$. Hydrolyses Tween 20 and hydrolyses Tween 80 weakly. Nitrate reduction is negative. $\beta$-Galactosidase, arginine dihydrolase, indole, urease and gelatinase are not produced and aesculin is not hydrolysed in API 20NE after $72 \mathrm{~h}$ of incubation. Aesculin and arbutin are not hydrolysed. Urease is positive after 4 weeks of incubation in urea broth. In the API 20NE system, gluconate, adipate, malate and citrate are used as carbon sources. Assimilation of glucose, L-arabinose, mannitol, mannose, $\mathrm{N}$-acetylglucosamine, maltose, caprate and phenylacetate is negative. In the API ID32GN system, assimilation of itaconate, suberate, lactate, 3-hydroxybenzoate, propionate, valerate and 3-hydroxybutyrate is positive. Assimilation of acetate, citrate, 4-hydroxybenzoate and L-alanine is weak. Assimilation of glucose, D-ribose, L-fucose, Larabinose, L-rhamnose, $\mathrm{N}$-acetylglucosamine, sucrose, maltose, melibiose, mannitol, inositol, sorbitol, salicin, glycogen, malonate, 5-ketogluconate, 2-ketogluconate, caprate, Lhistidine, L-serine and L-proline is negative. In the API ZYM system, production of alkaline and acid phosphatases, esterase (C4), esterase lipase (C8), leucine arylamidase, valine arylamidase and phosphohydrolase is positive and that of lipase (C14) is weak. Production of cystine arylamidase, trypsin, chymotrypsin, $\alpha$-galactosidase, $\beta$-galactosidase, $\beta$-glucuronidase, $\alpha$-glucosidase, $\beta$-glucosidase, $N$ acetyl- $\beta$-glucosaminidase, $\alpha$-mannosidase and $\alpha$-fucosidase is negative. Sensitive to penicillin, cefuroxim, ciprofloxacin, erythromycin, gentamicin, neomycin, polymyxin B and tetracycline. Resistant to ampicillin and cloxacillin. The DNA G + C content of the type strain is $61.9 \mathrm{~mol} \%$.

The type strain is SUEMI10 ${ }^{\mathrm{T}}\left(=\mathrm{LMG} 26149^{\mathrm{T}}=\mathrm{CECT}\right.$ $7840^{\mathrm{T}}$ ), isolated from soil on Tenerife (Canary Islands).

\section{Emended description of the genus Herbaspirillum Baldani et al. 1986}

The description of the genus Herbaspirillum is as given by Baldani et al. (1986), with the following amendments. Urease is positive or slowly positive. Assimilation of D-glucose, D-galactose, D-ribose, L-fucose, D-mannose, Larabinose, D-fructose, sorbitol, mannitol, L-proline, caprate, 5-ketogluconate and 2-ketogluconate is variable.

\section{Acknowledgements}

This work was supported by JCYL and MICINN (Spanish Government). A.V. was supported by a post-doctoral JAE-Doc (CSIC) contract. L. C. was supported by a post-doctoral contract supported by MICINN.

\section{References}

Alexander, D. B. \& Zuberer, D. A. (1991). Use of chrome azurol S reagents to evaluate siderophore production by rhizosphere bacteria. Biol Fertil Soils 12, 39-45.

Altschul, S. F., Gish, W., Miller, W., Myers, E. W. \& Lipman, D. J. (1990). Basic local alignment search tool. J Mol Biol 215, 403-410.

Baldani, J. I., Baldani, V. L. D., Seldin, L. \& Döbereiner, J. (1986). Characterization of Herbaspirillum seropedicae gen. nov., sp. nov., a root-associated nitrogen-fixing bacterium. Int J Syst Bacteriol 36, 86-93. 
Chun, J. \& Goodfellow, M. (1995). A phylogenetic analysis of the genus Nocardia with 16S rRNA gene sequences. Int J Syst Bacteriol 45, 240-245.

Chun, J., Lee, J. H., Jung, Y., Kim, M., Kim, S., Kim, B. K. \& Lim, Y. W. (2007). EzTaxon: a web-based tool for the identification of prokaryotes based on $16 \mathrm{~S}$ ribosomal RNA gene sequences. Int J Syst Evol Microbiol 57, 2259-2261.

Claus, D. \& Berkeley, R. C. W. (1986). Genus Bacillus Cohn 1872, $174^{\mathrm{AL}}$. In Bergey's Manual of Systematic Bacteriology, vol. 2, pp. 11051138. Edited by P. H. A. Sneath, N. S. Mair, M. E. Sharpe \& J. G. Holt. Baltimore: Williams \& Wilkins.

Ding, L. \& Yokota, A. (2004). Proposals of Curvibacter gracilis gen. nov., sp. nov. and Herbaspirillum putei sp. nov. for bacterial strains isolated from well water and reclassification of [Pseudomonas] huttiensis, [Pseudomonas] lanceolata, [Aquaspirillum] delicatum and [Aquaspirillum] autotrophicum as Herbaspirillum huttiense comb. nov., Curvibacter lanceolatus comb. nov., Curvibacter delicatus comb. nov. and Herbaspirillum autotrophicum comb. nov. Int J Syst Evol Microbiol 54, 2223-2230.

Dobritsa, A. P., Reddy, M. C. S. \& Samadpour, M. (2010). Reclassification of Herbaspirillum putei as a later heterotypic synonym of Herbaspirillum huttiense, with the description of $H$. huttiense subsp. huttiense subsp. nov. and $H$. huttiense subsp. putei subsp. nov., comb. nov., and description of Herbaspirillum aquaticum sp. nov. Int J Syst Evol Microbiol 60, 1418-1426.

Doetsch, R. N. (1981). Determinative methods of light microscopy. In Manual of Methods for General Bacteriology, pp. 21-33. Edited by P. Gerhardt, R. G. E. Murray, R. N. Costilow, E. W. Nester, W. A. Wood, N. R. Krieg \& G. H. Phillips. Washington, DC: American Society for Microbiology.

Ezaki, T., Hashimoto, Y. \& Yabuuchi, E. (1989). Fluorometric deoxyribonucleic acid-deoxyribonucleic acid hybridization in microdilution wells as an alternative to membrane filter hybridization in which radioisotopes are used to determine genetic relatedness among bacterial strains. Int J Syst Bacteriol 39, 224-229.

Felsenstein, J. (1983). Parsimony in systematics: biological and statistical issues. Annu Rev Ecol Syst 14, 313-333.

Im, W. T., Bae, H. S., Yokota, A. \& Lee, S. T. (2004). Herbaspirillum chlorophenolicum sp. nov., a 4-chlorophenol-degrading bacterium. Int J Syst Evol Microbiol 54, 851-855.

Jung, S. Y., Lee, M. H., Oh, T. K. \& Yoon, J. H. (2007). Herbaspirillum rhizosphaerae sp. nov., isolated from rhizosphere soil of Allium victorialis var. platyphyllum. Int J Syst Evol Microbiol 57, 2284-2288.

Kimura, M. (1980). A simple method for estimating evolutionary rates of base substitutions through comparative studies of nucleotide sequences. J Mol Evol 16, 111-120.

Kirchhof, G., Eckert, B., Stoffels, M., Baldani, J. I., Reis, V. M. \& Hartmann, A. (2001). Herbaspirillum frisingense sp. nov., a new nitrogen-fixing bacterial species that occurs in C4-fibre plants. Int $J$ Syst Evol Microbiol 51, 157-168.

Ludwig, W., Strunk, O., Westram, R., Richter, L., Meier, H., Yadhukumar, Buchner, A., Lai, T., Steppi, S. \& other authors (2004). ARB: a software environment for sequence data. Nucleic Acids Res 32, 1363-1371.
Mandel, M. \& Marmur, J. (1968). Use of ultraviolet absorbancetemperature profile for determining the guanine plus cytosine content of DNA. Methods Enzymol 12B, 195-206.

Poly, F., Monrozier, L. J. \& Bally, R. (2001). Improvement in the RFLP procedure for studying the diversity of nifH genes in communities of nitrogen fixers in soil. Res Microbiol 152, 95-103.

Rivas, R., García-Fraile, P., Mateos, P. F., Martínez-Molina, E. \& Velázquez, E. (2007). Characterization of xylanolytic bacteria present in the bract phyllosphere of the date palm Phoenix dactylifera. Lett Appl Microbiol 44, 181-187.

Rogers, J. S. \& Swofford, D. L. (1998). A fast method for approximating maximum likelihoods of phylogenetic trees from nucleotide sequences. Syst Biol 47, 77-89.

Rothballer, M., Schmid, M., Klein, I., Gattinger, A., Grundmann, S. \& Hartmann, A. (2006). Herbaspirillum hiltneri sp. nov., isolated from surface-sterilized wheat roots. Int J Syst Evol Microbiol 56, 1341-1348.

Saitou, N. \& Nei, M. (1987). The neighbor-joining method: a new method for reconstructing phylogenetic trees. Mol Biol Evol 4, 406425.

Sasser, M. (1990). Identification of bacteria by gas chromatography of cellular fatty acids, MIDI Technical Note 101. Newark, DE: MIDI Inc.

Sierra, G. (1957). A simple method for the detection of lipolytic activity of micro-organisms and some observations on the influence of the contact between cells and fatty substrates. Antonie van Leeuwenhoek 23, 15-22.

Stoltzfus, J. R., So, R., Malarvithi, P. P., Ladha, J. K. \& deBruijn, F. J. (1997). Isolation of endophytic bacteria from rice and assessment of their potential for supplying rice with biologically fixed nitrogen. Plant Soil 194, 25-36.

Tamura, K., Dudley, J., Nei, M. \& Kumar, S. (2007). MEGA4: molecular evolutionary genetics analysis (MEGA) software version 4.0. Mol Biol Evol 24, 1596-1599.

Thompson, J. D., Gibson, T. J., Plewniak, F., Jeanmougin, F. \& Higgins, D. G. (1997). The CLUSTAL_X windows interface: flexible strategies for multiple sequence alignment aided by quality analysis tools. Nucleic Acids Res 25, 4876-4882.

Trujillo, M. E., Fernández-Molinero, C., Velázquez, E., Kroppenstedt, R. M., Schumann, P., Mateos, P. F. \& Martínez-Molina, E. (2005). Micromonospora mirobrigensis sp. nov. Int J Syst Evol Microbiol 55, 877-880.

Valverde, A., Velázquez, E., Gutiérrez, C., Cervantes, E., Ventosa, A. \& Igual, J. M. (2003). Herbaspirillum lusitanum sp. nov., a novel nitrogen-fixing bacterium associated with root nodules of Phaseolus vulgaris. Int J Syst Evol Microbiol 53, 1979-1983.

Wayne, L. G., Brenner, D. J., Colwell, R. R., Grimont, P. A. D., Kandler, O., Krichevsky, M. I., Moore, L. H., Moore, W. E. C., Murray, R. G. E. \& other authors (1987). International Committee on Systematic Bacteriology. Report of the ad hoc committee on reconciliation of approaches to bacterial systematics. Int J Syst Bacteriol 37, 463-464.

Willems, A., Doignon-Bourcier, F., Goris, J., Coopman, R., de Lajudie, P., De Vos, P. \& Gillis, M. (2001). DNA-DNA hybridization study of Bradyrhizobium strains. Int J Syst Evol Microbiol 51, 1315-1322. 